\title{
Combining inland and offshore paleotsunamis evidence: the Augusta Bay (eastern Sicily, Italy) case study
}

\author{
A. Smedile, P. M. De Martini, and D. Pantosti \\ Istituto Nazionale di Geofisica e Vulcanologia, Via di Vigna Murata, 605, 00143 Rome, Italy
}

Correspondence to: A. Smedile (alessandra.smedile@ingv.it)

Received: 4 October 2011 - Revised: 6 April 2012 - Accepted: 4 May 2012 - Published: 14 August 2012

\begin{abstract}
Offshore and inland geological evidence for multiple tsunami inundations was found in the Augusta Bay area: (1) the main local historical tsunamis (1908, 1693, 1169), (2) two far-generated tsunamis (i.e. Crete $365 \mathrm{AD}$ and Santorini, 3600 BP), and (3) seven unknown tsunamis). Average tsunami recurrence intervals from inland and offshore investigations of about 550 and $320 \mathrm{yr}$, respectively were obtained for the past $4 \mathrm{ka}$. The history of paleotsunamis from the marine record appears to be as complete as the historical one for the past millennium, yielding an average tsunami recurrence interval of $250 \mathrm{yr}$ for the Augusta Bay. Geological data allow also estimating a minimum tsunami inundation distance of $530 \mathrm{~m}$ and a minimum run-up of $5 \mathrm{~m}$. The marine record contains evidence for more paleotsunamis with respect to the inland one because of continuous sedimentation and better preservation of stratigraphy in the offshore with respect to coastal areas, which are commonly affected by intermittent-erosion and sedimentation and anthropic activities.

This work shows that the integration of geological and historical data can provide critical information regarding the extent and age of tsunamis of the past (e.g. inundation distance, age, and frequency), which is of immediate relevance for tsunami hazard assessment.
\end{abstract}

\section{Introduction}

After the 2004 Sumatra deadly event, the 2011 Japan gigantic earthquake and tsunami has recalled attention on prevention actions based on reliable earthquake shaking and tsunami inundation scenarios coupled with their probability of occurrence. During the past decades, earthquake shaking scenarios and models of earthquake occurrence were largely developed worldwide using different approaches and provided the critical information for seismic risk analyses. Differently, since tsunamis are more rare events, the diffusion of such analyses and models applied to these occurrences is still limited and restricted to a few well-studied areas (e.g. Cascadia, Sumatra and Japan). The occurrence of recent large tsunamis has certainly started creating awareness about the fact that most of the coastal areas in seismically active regions may suffer from destructive tsunami inundations and that some regions can even be hit by large waves originating from transoceanic sources (teletsunamis). This is true also for the Mediterranean area where, although science has substantially progressed, a regional tsunami hazard assessment and a basin-wide tsunami early warning system are still in a very initial stage.

One critical issue in building a reliable tsunami hazard assessment is the availability of input data to construct the tsunami history of the region. This is traditionally done on the basis of instrumental (few cases in the Mediterranean) and historical records that supply information for the past century or few millennia, respectively. However, several works worldwide (e.g. Atwater and Moore, 1992; Shiki et al., 2008 and references therein) have highlighted that a significant contribution to obtain a complete reconstruction of the tsunami history of an area can be provided by geological data (e.g. geomorphological, sedimentological, paleontological, geochronological and sea-level data). In fact, similarly to the paleoseismological approach, the recognition and dating of the geological signatures of tsunamis of the past (named also paleotsunamis in the following) allow to extend back in time the tsunami history of a specific area from the century-millennium time-window of the instrumental-historical data to several millennia. Thus, integrating information from instrumental, historical and 
geological data is the key to obtain a representative long-term model of tsunami occurrence. Moreover, geological data on actual inundation distances related to paleotsunamis are also extremely critical to constrain and validate inundation maps as well as to test tsunami scenarios. In estimating the inland inundation distance of paleotsunamis, we should also consider that, according to Lambeck et al. (2004) and Antonioli et al. (2009), the sea level was possibly a few meters lower than at present. This latter information, combined with the fact that the inland paleotsunami geologic record clearly underestimates the inundation distance (Goto et al., 2011), stresses the fact that the geologically derived inundations should be considered as minima.

Only recently has research on the tsunami geological record started also in the Euro-Mediterranean area (e.g. Dawson et al., 1995; Bondevik et al., 1997; Hindson et al., 1999; Dominey-Howes et al., 2000; Minoura et al., 2000; Gianfreda et al., 2001; De Martini et al., 2003). In most of the cases, geological signatures of paleotsunamis are found inland and are represented by the deposits left by the tsunamis on coastal areas; usually, these appear as allochthonous high-energy marine layers within low-energy continental stratigraphic sequences (Atwater and Moore, 1992; De Martini et al., 2003; Cochran et al., 2006). Also, the presence of boulders and megaclasts abandoned along low coastal areas may be the result of inland transportation of tsunami waves (Mastronuzzi et al., 2007; Scicchitano et al., 2007; Barbano et al., 2010). Tsunami signatures are only rarely found as stratigraphic disturbances in the offshore sediments (Weiss and Bahlburg, 2006; Dawson and Stewart, 2007). In fact, in the Mediterranean, tsunamis have been mainly recognized as the triggering mechanism of some turbidites found in the abyssal plains (e.g. Cita and Aloisi, 2000 and references therein) or as coarse-grained sediments in the nearshore, interpreted as deposits of backwash waves (e.g. Goodman-Tchernov et al., 2009).

The strength of the reconstruction of the tsunami history of a region for tsunami hazard purposes is substantially improved when a convergence of different observations supporting the occurrence of a tsunami is found (e.g. historical, geological offshore, and geological inland data); this is quite rare though.

In this paper, we present an exceptional case for which historical and geological evidence (inland and offshore data already published in De Martini et al., 2010 and Smedile et al., 2011, respectively) of past tsunamis can be combined. These data were collected and integrated to build up a 4000 yr-long tsunami history in eastern Sicily. We focused on the Augusta Bay (Fig. 1), which was repeatedly hit by tsunami waves related to large $(M>6.5)$ local historical earthquakes: e.g. 1908, 1693, 1542, 1169 (CPTI Working group, 2004) as well as to far-field sources, e.g. $365 \mathrm{AD}$ Crete earthquake (Jerome, 380). Tsunami inundation in the Augusta Bay is reported in the historical documents with the 1693 event being the worst-case, producing a maximum

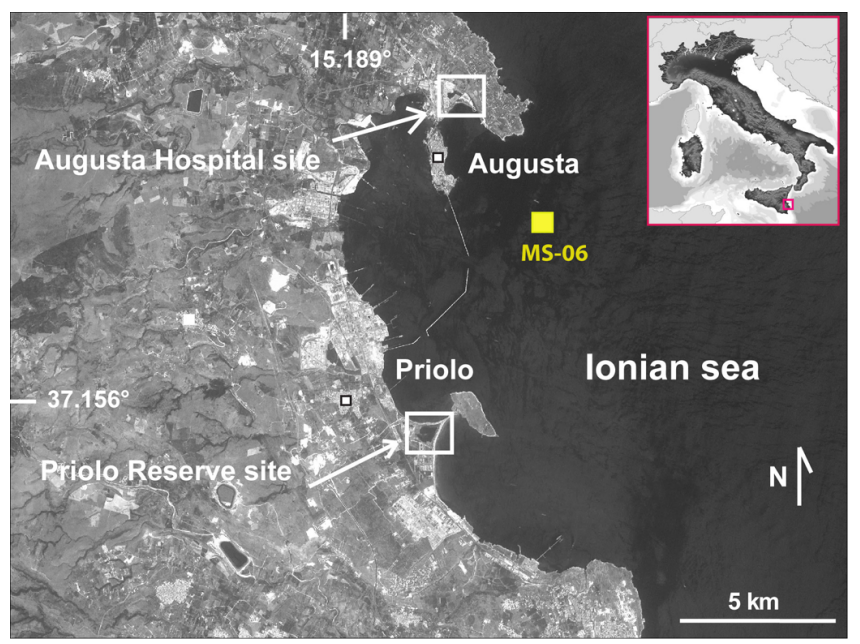

Fig. 1. Location of the Augusta Bay in eastern Sicily, Italy. The Augusta Hospital and Priolo Reserve sites are marked with white empty rectangles, while a yellow box locates the offshore coring site (MS-06). The small white filled squares indicate the Augusta and Priolo downtown.

inland inundation as much as $165 \mathrm{~m}$ and run-up values of 2.4 to $8.0 \mathrm{~m}$ (see Gerardi et al., 2008 and references therein for details).

The Augusta Bay is a natural gulf about $15 \mathrm{~km}$ wide and with a $25 \mathrm{~km}$-long shoreline. The outcropping rocks near the bay are mainly made up of Pleistocene sediments that rest unconformably upon Miocene shallow water carbonates with intercalated volcanic rocks (Grasso et al., 1982; Carbone, 1984). It is interesting to note that there is no important drainage flowing into the bay; therefore, the inland sediments are not a major source of material for the offshore. Several ponds and lowlands follow the coast behind the dunes. Some of them have been transformed into salt pans since Greek times.

In the following we present the different approaches we developed to recognize and characterize tsunami sediments inland and offshore; we discuss the main results in order to integrate them with the knowledge derived from the historical record of tsunamis.

\section{Methodology}

Tsunamis can induce modification and sedimentation both in off-shore and inland environments. A large variability of sedimentation patterns and structures can occur depending on the type of environment affected by the tsunami and especially on the geomorphic setting both underwater and inland (Sugawara et al., 2008).

The definition of a tsunami deposit is based on the recognition and characterization of a high-energy marine deposit that is, in some way, allochthonous to the stratigraphy hosting it and that contains morphological, sedimentological, 
paleoecological, and paleontological characteristics that are compatible with the tsunami action/modification. This is the case both for tsunami deposits found inland (within continental deposition) and offshore (within low-energy marine deposits).

To recognize and investigate paleotsunami deposits in the Augusta Bay, we developed a multidisciplinary approach that is very similar both inland and offshore and comprises three main steps:

Step 1 - Site selection.

Geomorphic/bathymetric/geophysical and geological investigations to identify sites favourable to sedimentation, preservation and dating of tsunami deposits. We used aerial photographs and satellite images interpretation, coupled with field surveys, along the Augusta Bay coastline to highlight the presence of lowlands and lagoons along the whole coastal area; these represent excellent and convenient restricted traps of where to search and identify paleotsunami deposits (Shiki et al., 2008). Offshore, we searched for a location characterized by low energy, lack of erosion and modification to sample a potentially complete and undisturbed stratigraphic record; this was done using a close-spaced grid of seismic reflection chirp sonar profiles covering ca. $150 \mathrm{~km}^{2}$. Through this survey we investigated the morphobathymetry and seafloor reflectivity and reconstructed a relatively wide continental shelf comprising a thick late Holocene record. There, we selected a site where the undisturbed Holocene layers may contain the record of paleotsunamis.

Step 2 - Sampling procedure.

Collection of sediment cores both offshore and inland. Tens of cores were collected inland prevalently at two sites (Augusta and Priolo, Figs. 1 and 2) using both hand auger equipment and a vibracoring (gasoline powered percussion hammer), always accompanied by GPS surveys for its exact positioning with respect to the present shoreline. Additionally, one $6.7 \mathrm{~m}$-long piston core was collected in the northern shelf of the bay.

Step 3 - Identification and characterization of paleotsunami deposits.

Characterization of the nature, environment of deposition, and age of the collected sediments through several laboratory analyses (X-ray, physical properties, grain size, micropaleontological, radiometric datings, morphoscopic and glass chemistry on tephra). These analyses allow correlating key layers in the sediment columns that may be directly or indirectly related to a tsunami.

The results from these three steps were then compared and integrated with pre-existing knowledge on tsunami of the past, mainly derived from historical reports.

\section{Results and interpretation}

\subsection{Inland evidence for tsunamis}

As mentioned in the previous section, we performed geomorphological investigations of the Augusta Bay coastal area by searching for marshes or lagoons. This geomorphologic study was difficult and the site selection quite limited, because most of the area facing the sea is occupied by large petrochemical facilities, NATO and Italian Navy bases.

We selected only sites wide enough to perform our coring campaigns at different locations with respect to the present shoreline, in general starting from a minimum distance of $200 \mathrm{~m}$, then moving further inland as much as possible. This approach was applied in order to reduce the influence of (1) erosion/deposition processes related to storms, typically restricted to about $200 \mathrm{~m}$ from the shore even in case of hurricanes or typhoons (Morton et al., 2007), and (2) tsunami-related erosion/bypass zone (no deposition) processes, usually occurring as far as $150 \mathrm{~m}$ inland (Gelfenbaum and Jaffe, 2003). Setting the sites at a distance $>200 \mathrm{~m}$ from the present coastline is a very conservative choice; in fact, analyzing the anemometric and ondametric data for the period 1989-2006, we could verify that the strongest recorded storms in the Augusta Bay area had an inundation distance confined within $55 \mathrm{~m}$ from the coastline (details can be found in De Martini et al., 2010).

We focused our study on the sites of Augusta Hospital and Priolo Natural Reserve, located about $10 \mathrm{~km}$ apart (Fig. 1). The Augusta Hospital site is located at the N-NE part of the bay close to the old Augusta town and is placed on an up to $5 \mathrm{~m}$ a.s.l. alluvial surface, gently dipping westward towards a large salt marsh bounding the sea (about $0.3 \mathrm{~km}^{2}$ wide, it was the ancient salt pan of the town, Fig. 2c). The Priolo site is a $0.5 \mathrm{~km}^{2}$-wide, shallow, coastal lagoon separated from the sea, both to the $\mathrm{N}$ and to the $\mathrm{E}$ by a series of sand dunes, up to $4.5 \mathrm{~m}$ high (Fig. 2d). The lagoon is generally completely dry during summer. At both sites, part of the lowlands was used to produce marine salt, fundamental for the local fish preservation factories (sometimes since Greek times, more than $2.5 \mathrm{ka}$ ago). Salt pans are related to the presence of a low-energy protected environment, close to the sea, that lasted a long time and with no important coastal changes occurring at least for $2000 \mathrm{yr}$, as also confirmed by our paleoenvironmental analysis.

A total of 22 cores were collected inland in these two sites (Fig. 2). The longest core reached a depth of about $4.3 \mathrm{~m}$, and the maximum sampling distance from the present coastline was $530 \mathrm{~m}$ (De Martini et al., 2010).

By merging all the available data from the cores at the Augusta Hospital site, the sedimentary sequence can be synthesized as follows (Fig. 2e). From $-4.3 \mathrm{~m}$ up to $-1.0 \mathrm{~m}$, the sequence is dominated by an alternation of dark brown to gray clayey silt to silt layers with a few sparse weathered 


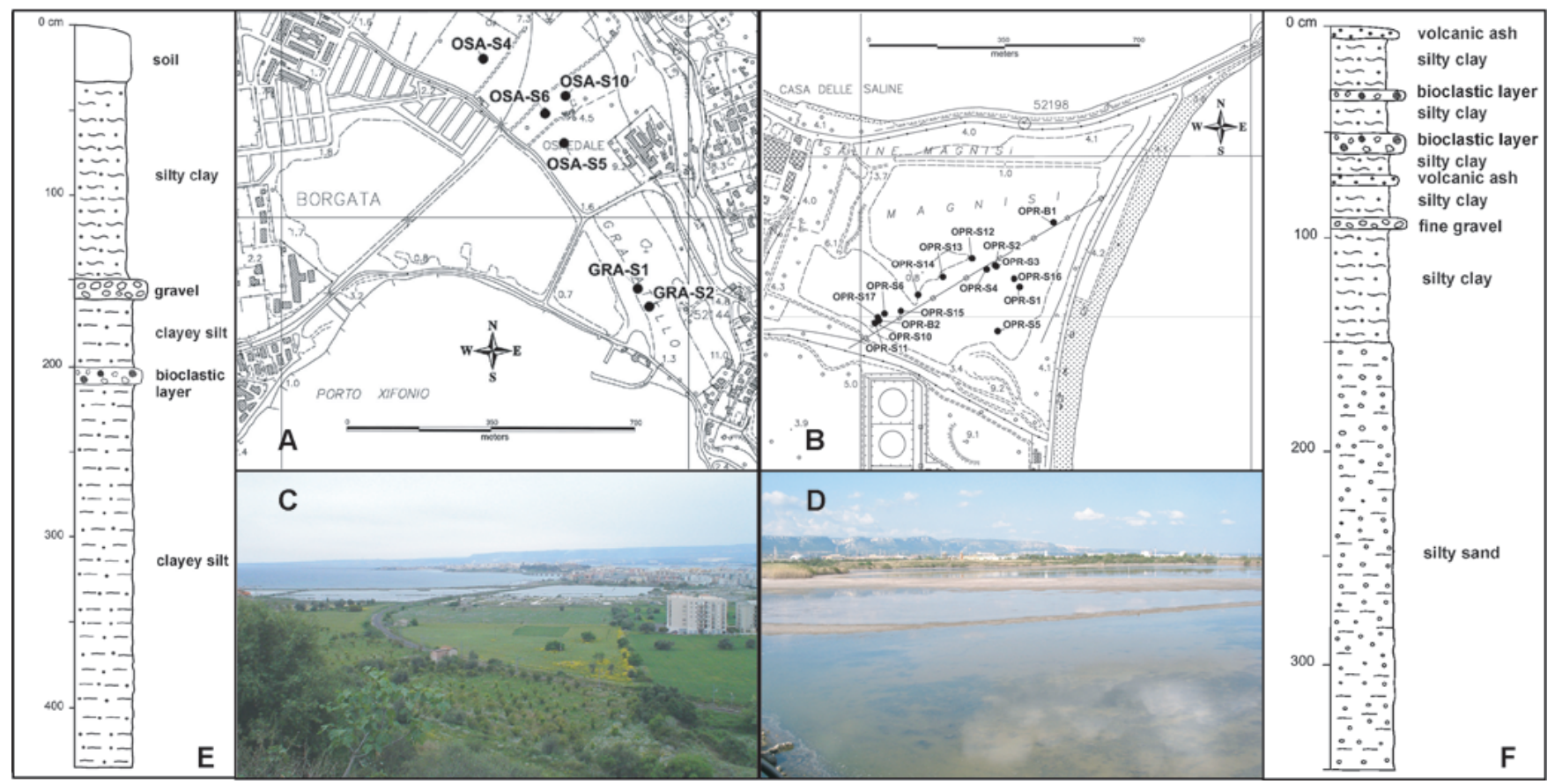

Fig. 2. Locations of cores collected at the Augusta Hospital (A) and Priolo Reserve (B) sites (topographic maps from the Regional Technical Cartography, RTC scale 1:10000). Views of the Augusta Hospital (C, looking S) and Priolo Reserve (D, looking N) areas. Schematic sedimentary sequences for Augusta (E) and Priolo (F) sites.

pebbles and with frequent plant remains and shell fragments; from $-1.0 \mathrm{~m}$ to $-0.3 \mathrm{~m}$, the deposit comprises brown to hazel silty clay to clayey silt levels, with sparse clasts, small macrofossil fragments and plant remains; from $-0.3 \mathrm{~m}$ to the ground, there is dark brown plowed soil (with several roots, small pebbles and brick fragments). The fine-grained sequence between -4.3 and $-1.0 \mathrm{~m}$ is interrupted by a distinctive bioclastic deposit and by a gravel layer at about -2.0 and $-1.5 \mathrm{~m}$, respectively (Fig. 3a). Both suggest the occurrence of high-energy depositional events, being characterized by an anomalously high shell detritus content, coupled with the presence of planktic and marine benthic Foraminifera (Fig. 3a, green box), totally allocthonous to the lagoonal deposits above and below (Fig. 3a, yellow box). The foraminiferal analysis shows that the brackish lagoonal environment deposition, which prevailed between -4.3 and $-1.0 \mathrm{~m}$, was followed by a sudden change to a marine environment. This abrupt environmental change is suggestive of the occurrence of another high-energy event that impacted so strongly the coastline to induce a sudden change in its morphology.

At the Priolo Reserve site, stratigraphic changes are common, moving from the central part of the lagoon southwestward and eastward, where the sand dune system tends to strongly influence the local sedimentation. Notably, the most interesting area was the southwestern sector of the lagoon, for which, by merging the available data from the cores, we were able to synthesize a schematic stratigraphic sequence (Fig. 2f). From $-3.5 \mathrm{~m}$ up to $-1.5 \mathrm{~m}$, the sequence is mainly composed of yellowish silty sand with sparse carbonatic clasts, while from $1.5 \mathrm{~m}$ of depth up to the surface, it is composed of gray to brown silty clay to clayey silt deposits, with shell fragments, plant remains and whole bivalves and gastropods. The uppermost $1.5 \mathrm{~m}$ of fine-grained deposits are interrupted by two distinctive bioclastic layers at about -0.3 and $-0.5 \mathrm{~m}$ (Fig. 3b): by one dark brown volcanic ash at about $-0.7 \mathrm{~m}$ and by a detritic deposit at $-0.9 \mathrm{~m}$. The micropaleontological analysis indicates that the silty clay sequence belongs to a low-energy lagoonal environment (Fig. 3b, yellow box) from the surface down to $1.5 \mathrm{~m}$, with the exceptions represented by the coarse-grained layers (two bioclastic and one mixed layer including detritic, organic and bioclastic components). In fact, being characterized by an abnormal concentration of shell fragments, whole gastropods arranged in a chaotic pattern together with badly preserved benthic and planktic Foraminifera (Fig. 3b, orange box), these are high-energy deposits of clear marine origin.

Another peculiar high-energy layer of marine origin was found at about $-1.6 \mathrm{~m}$ in the southeastern sector of the lagoon. This is a distinct, dark gray, fine sandy layer containing marine microfauna (benthic and few planktic Foraminifera), as well as marine macrofauna, well preserved and different from the rare and poorly preserved paleontological lagoonal association characterizing the fine-grained deposits above and below it. 


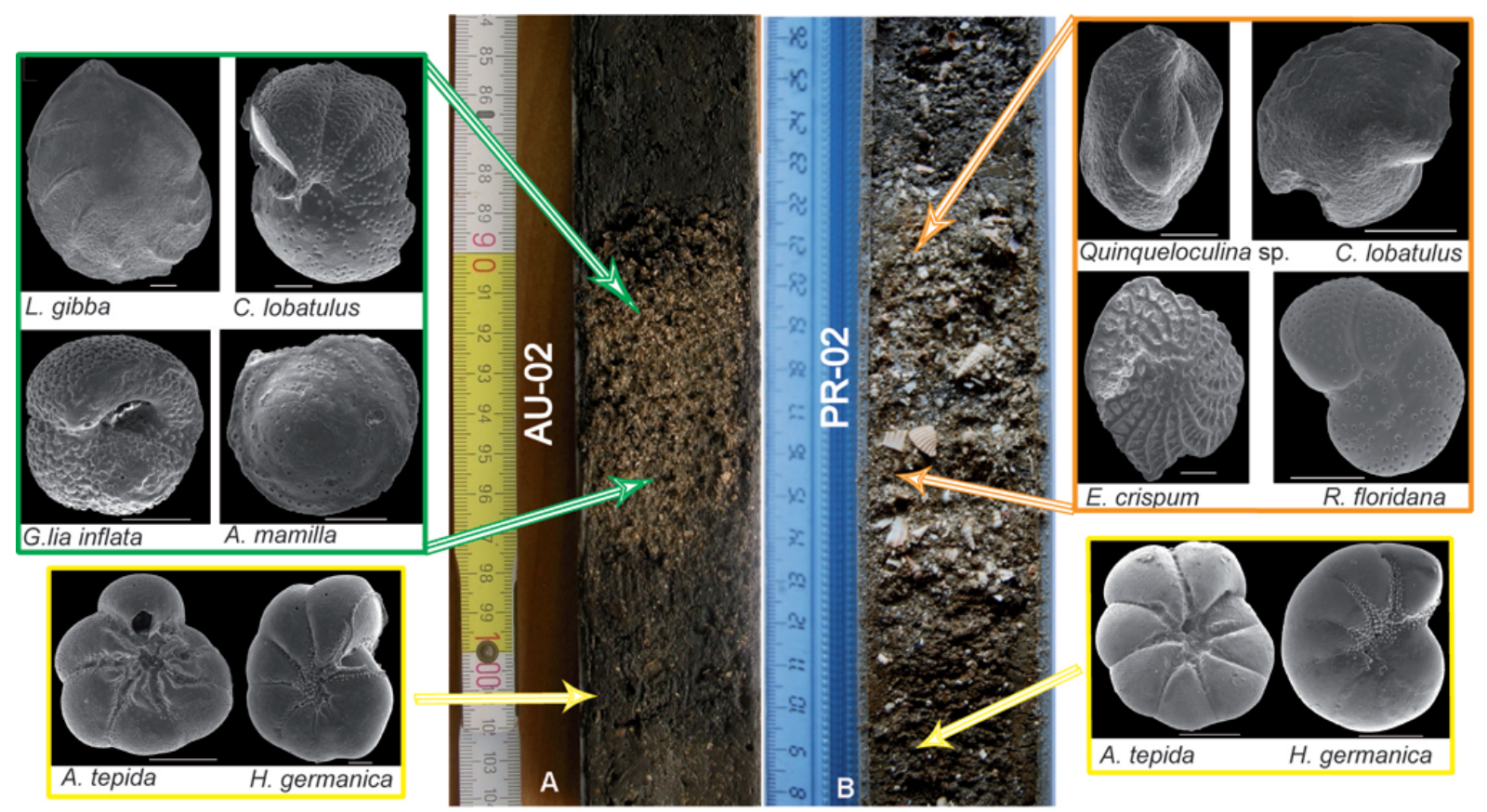

Fig. 3. Examples of paleotsunami deposits found at the two Augusta Bay inland sites. (A) Augusta site: picture of the bioclastic layer (event AU-02 from the OSA-S6 core found at $-1.95 \mathrm{~m}$ of depth) showing a sharp erosional basal contact and no evidence for internal structures or grading. The FESEM images on the left (the scale bar below each pictures represent $100 \mu \mathrm{m}$ ) show some selected Foraminifera found in coincidence of the bioclastic layer (green box) and just above and below it (yellow box). (B) Picture of a bioclastic layer with sharp (probably erosional) basal contact (event PR-02 from the OPR-S11 core found at $-0.60 \mathrm{~m}$ of depth), displaying a large amount of shell fragments and gastropods (Pirenella conica, with abrasions probably due to high energetic transport). FESEM images on the right show selected Foraminifera collected within the high-energy layer (orange box) and above and below it (yellow box). The Foraminifera in the yellow boxes are typical of lagoonal environments, whereas those in the green and orange boxes are typical of open marine environments.

The stratigraphic, sedimentologic and micropaleontologic results at both sites have highlighted that the dominant stratigraphy in the area is characterised by fine to very fine sediments of a lagoonal environment, and by at least seven high-energy intervening deposits, of clear marine origin, repeatedly found in several cores. Among these, six share the same characteristics (Fig. 3): they are massive, structureless, relatively thin (up to $10 \mathrm{~cm}$ maximum) and commonly fining upwards, with an abrupt lower contact sometimes erosive; often they display an important amount of shell fragments and plant remains; they also contain benthic and planktic Foraminifera from shallow to open sea, with an increment in the benthic Foraminifera-specific diversity as well as a very different paleontologic association with respect to the deposits above and below them. The seventh high-energy deposit is characterized by an abrupt granulometric and environmental change that contrasts with the previous lagoonal deposits (see De Martini et al., 2010 for details).

Chronological constraints on the age of these deposits are based on 8 AMS ${ }^{14} \mathrm{C}$ datings of samples collected in the cores and on the attribution by petro-chemical and morphoscopic analyses of a tephra layer found at Priolo site to the $122 \mathrm{BC}$ Etna eruption (De Martini et al., 2010). For the ${ }^{14} \mathrm{C}$ dated marine shells, calibration was performed by adopting the reservoir correction for marine samples $(400 \mathrm{yr}$ according to the calibration data set marine 04.14c; see Calib REV5.0.2 by Stuiver and Reimer, 2005) and the local $\Delta R$ for reservoir age (more details can be found in De Martini et al., 2010). On this basis the seven high-energy events (named AU- and PR-events depending if found at Augusta or Priolo sites) are dated as follows: younger than 1420-1690 AD (PR-01), 650-770 AD (AU-00), 160-320 AD (PR-02), 600-400 BC (AU-01), 800-600 BC (PR-03), 975-800 BC (AU-02) and 2100-1635 BC (PR-04).

In summary, integrating data from the Augusta Hospital (AU-events) and Priolo Reserve (PR-events) sites during the past $4 \mathrm{ka}$, we suggest that evidence for seven tsunamis was found (De Martini et al., 2010).

\subsection{Offshore evidence for tsunamis}

Offshore studies offer an interesting alternative to the investigation of tsunami's signatures, because marine environments can assure a relatively undisturbed continuous record and, therefore, are potentially more sensitive to anomalous events (i.e. earthquakes and tsunamis). Even so, very little has been done on the study of tsunami transport 
and deposition in offshore zones or in shallow-shelf areas (Weiss and Bahlburg, 2006; Dawson and Stewart, 2007). Coarse-grained deposits and, more generally, high-energy processes were used as offshore evidence for paleotsunamis (van den Bergh et al., 2003; Reinhardt et al., 2006; Abrantes et al., 2008; Goodman-Tchernov et al., 2009). In addition, these studies highlighted the difficulty in differentiating tsunami effects from those of common storms in the near-shore zone, and in addressing the problem of the subtle mixing of the two processes.

Because of the possibility to test the significance of potential offshore paleotsunami proxies on the basis of historical data and paleotsunami evidence inland, we explored the Augusta Bay offshore (Smedile et al., 2011). We used a close-spaced grid of seismic reflection chirp sonar profiles to reconstruct the bay morphology, which is characterized by a narrow shelf and a relatively steep slope located approximately $5-7 \mathrm{~km}$ from the shoreline. The northern part of the bay is characterized by widest shelf with fine-grained deposits and absence of gravitational processes and anthropogenic disturbances (both in terms of sediment quality and of local sedimentation rate due to dumping).

Thus, because this part of the bay appears stable and characterized by a low-energy environment, we chose this area for collecting a $6.7 \mathrm{~m}$-long piston core (MS-06). The coring site is located $2 \mathrm{~km}$ offshore the Augusta harbour at $72 \mathrm{~m}$ water depth (Fig. 1). Through detailed multidisciplinary analyses of this core, we started a "blind" search for any subtle anomaly in sediments, faunal assemblages, physical properties, etc. that could represent a proxy for a tsunami occurrence.

The MS-06 core comprises an almost homogeneous gray mud only interrupted at $3 \mathrm{~m}$ below the top by a $3-4 \mathrm{~cm}$ thick, black, medium-coarse sandy layer, very rich in magnetic minerals of volcanic origin, located at (Fig. 4). X-Ray imaging highlighted also several few $\mathrm{cm}$-thick dark horizons, likely related to the compaction of Posidonia oceanica remains.

A multivariate cluster analysis (Q-mode and R-mode hierarchical cluster analysis) on the benthic foraminiferal assemblage was carried out in order to separate "naturally occurring groups" and quantify the relationship between groups. Therefore, according to Q-mode analysis, the benthic foraminiferal assemblage was subdivided into two main groups that we named Clusters A and B (see for details Smedile et al., 2011). Cluster A groups species that are living in an inner shelf environment with a muddy substratum rich in organic matter (Biofacies IV of Jorissen, 1987), whereas Cluster B groups only epiphytic taxa that are normally living in the infralittoral zone on vegetated and coarse substrates such as the Posidonia oceanica prairies. The species from Cluster A can be considered as the autochthonous assemblage, coherent with the sampling core depth (72 mb.s.1.) and the muddy prevailing stratigraphy. On the contrary, Cluster B species can be interpreted as displaced (or transported) from shallow depths (max about $40 \mathrm{~m}$ b.s.l. when taking into account the deepest limit of the living zone of Posidonia oceanica to which these taxa usually live attached). Moreover, as shown by the R-mode analysis, samples containing an abundance $\geq 25 \%$ of displaced epiphytic Foraminifera (belonging to Cluster B) occur at 12 layers often centred on a peak value (Fig. 4). These microfaunal anomalies were generally accompanied by a significant amount of plant remains in the washed fraction, by localized concentration of gastropods (mainly Turritella communis, sometimes arranged without directional pattern) and coincide with the darker bands, as highlighted by the $\mathrm{X}$-ray imaging.

Besides the benthic specimens, planktic Foraminifera were counted and identified at generic level due to their low frequencies. The ratio between plankton and benthos (P/B ratio) is normally assumed to be correlated to the bathymetry. The P/B ratio values found in MS-06 are not constant, they range between $1.61 \%$ and $14.24 \%$ and show a trend, with negative deflections in coincidence of almost all benthic displacement layers (Fig. 4). This trend is interpreted as a possible drowning of the living assemblage caused by the presence of the displaced epiphytic Foraminifera more than a change in the bathymetry. In fact, low $\mathrm{P} / \mathrm{B}$ ratio values are coherent with the sampling depth of the MS-06 core and indicate that no significant bathymetric change occurred.

Moreover, grain-size analyses (Smedile et al., 2011), which showed a predominant silty sedimentation, highlight sandy inputs correlated with the 12 anomalous intervals (Fig. 4). The sandy component appeared to be uncommon at the MS-06 site and occurred only in specific portions of the core. As for the displaced epiphytic microfauna, the no-null value sand samples tended to be grouped in somehow distinct layers. Looking in detail at the grain size cumulative curves, coincident with some of the most prominent sand/transported epiphytic foraminiferal input, a peculiar bimodal grain-size distribution was noticed. This is interpreted as the result of a depositional mechanisms and/or sand sources that represent an anomaly in the deposition of the core sediments. In fact, this bimodal distribution is absent in the samples above and below as well as in correspondence with other sand-rich layers that are not correlated with the 12 displaced Foraminifera layers.

Chronological constraints for the cored sediments are derived from tephrostratigraphy, AMS ${ }^{14} \mathrm{C}$ dating, and radioactive tracers $\left({ }^{210} \mathrm{~Pb}\right.$ and $\left.{ }^{137} \mathrm{Cs}\right)$. All the results consistently attribute the whole core sequence to the past 4500 yr. ${ }^{14} \mathrm{C}$-measured ages were dendrochronologically corrected according to the radiocarbon calibration program OxCal 4.1 (Bronk Ramsey, 2009), using a global marine calibration curve and an appropriate $\Delta R$ offset (i.e. the local correction) selected from the CHRONO Marine Reservoir Database (Reimer and Reimer, 2001). The tephra layer found in the MS-06 core was attributed to the 122 BC Etna eruption, the same found onshore in the Priolo cores. Radioactive 


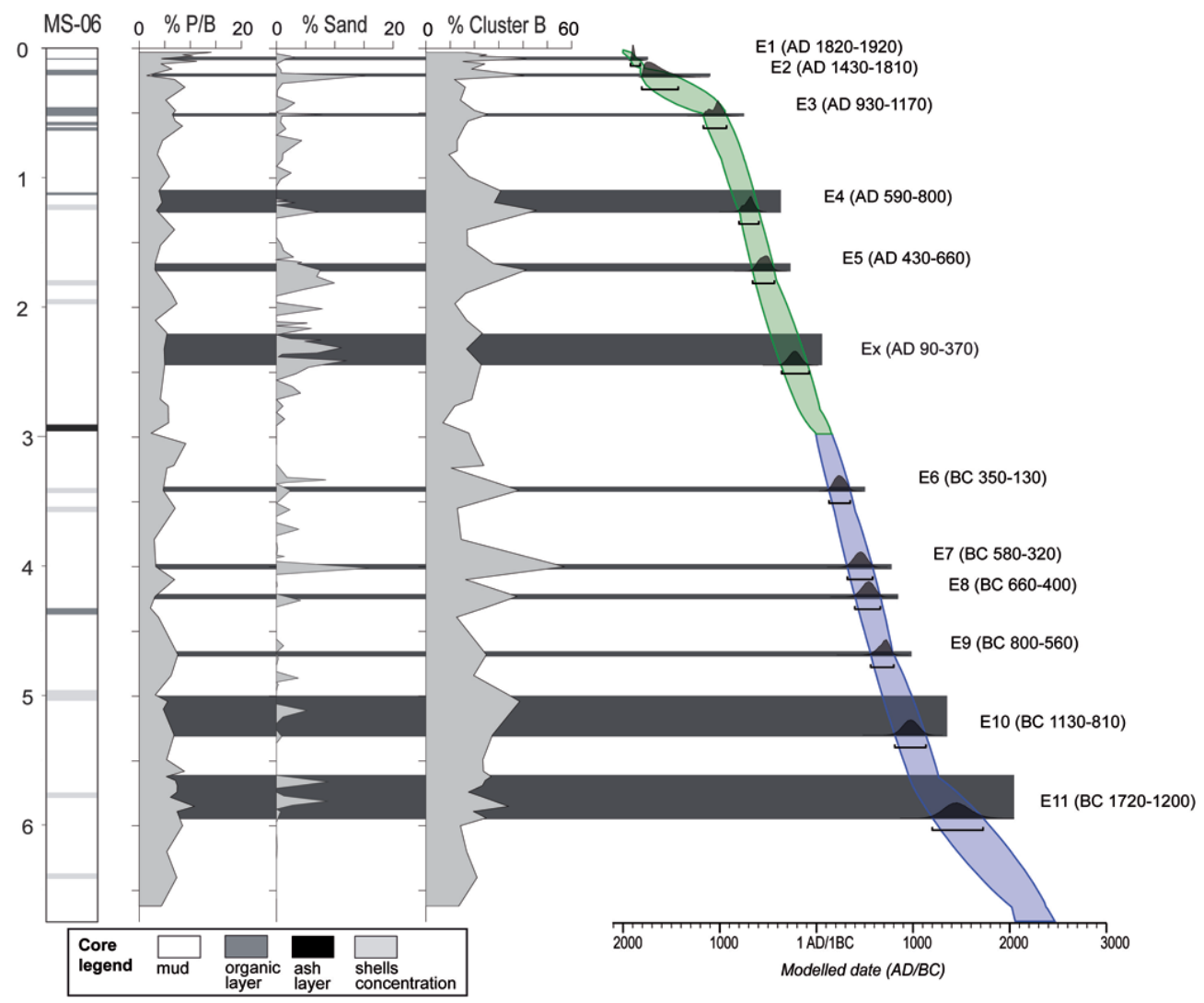

Fig. 4. Simplified log of the MS-06 core, plankton and benthos ratio ratio (P/B), sand distribution, and concentration of epiphytic displaced species. The gray horizontal bands highlight the 12 intervals of positive correlations between sedimentological and foraminiferal characteristics. On the right part of the figure, the age-depth model, built on the basis of a P_sequence from OxCal 4.1software (Bronk Ramsey, 2008) with the probability distribution ranges $(2 \sigma)$, is shown. The change in colour of the age-depth model represents a strong boundary change inserted in coincidence of the Etna tephra (122 BC). The 12 layers are dated following this age model, assuming the age of the deposit at the base of each of them as the closest to the beginning of the exceptional high-energy episode.

tracers yielded an average sedimentation rate of $0.7 \mathrm{~mm} \mathrm{yr}^{-1}$ for the uppermost $15 \mathrm{~cm}$, confirming the presence of XX century sediments in the core. Merging all these data by means of the OxCal software, we obtained a depositional model (Bronk Ramsey, 2008) that helped us to provide an age range for the 12 high-energy signature intervals (Fig. 4) as follows: 1820-1920 AD (E1), 1430-1810 AD (E2), 930-1170 AD (E3), 590-800 AD (E4), 430-660 AD (E5), 90-370 AD (Ex), 350-130 BC (E6), 580-320 BC (E7), 660-400 BC (E8), 800-560 BC (E9), 1130-810 BC (E10), 1720-1200 BC (E11).

Summarizing, the 12 intervals characterized by an abundance $\geq 25 \%$ of displaced benthic Foraminifera, a relative increase in the fine sand component, a negative deflection in the $\mathrm{P} / \mathrm{B}$ trend, the presence of dark horizons in the X-ray imaging, and a localized concentration of gastropods (Fig. 4) can represent episodic high-energy events related to a distinctive mechanism of emplacement (i.e. tsunami).

\section{Discussion}

We have investigated the Augusta Bay in eastern Sicily by searching for the geological evidence of the historical tsunamis that are known to have hit this area (Tinti et al., 2007) and also of previous unknown ones. The study comprises both inland and offshore investigations. The inland study shows evidence for seven high-energy events in the past $4.1 \mathrm{ka}$, whereas the offshore study provided evidence for 12 high-energy events in the past $3.7 \mathrm{ka}$. Age of these events was established on the basis of the integration of ${ }^{14} \mathrm{C}$ dating, tephrochronology, and radioactive tracers $\left({ }^{210} \mathrm{~Pb}\right.$ and $\left.{ }^{137} \mathrm{Cs}\right)$. We interpret these events as evidence for the occurrence of paleotsunamis and exclude that they could represent the signature of storms for the following reasons: (1) inland stratigraphic evidence was collected at greater distance from the coastline with respect to the maximum inundation distance related to large storms in this area, which is confined within about $55 \mathrm{~m}$ from the shoreline; (2) offshore storm signatures are restricted to the near-shore area (a few hundreds of metres from the coastline), whereas 
the MS-06 core is located more than $2 \mathrm{~km}$ from the coast; (3) tsunami waves are characterized by longer wavelengths and more erosional potential than storms, being a more efficient mechanism and able to transport epiphytic species from their living zone (up to $35-40 \mathrm{~m}$ b.s.l.) to greater depths (72 mb.s.l. - core location) along with some amount of sand. Moreover, because of the lack of inland drainages, submarine channels, and major slumps, we can exclude also any other mechanism that could have led to the transport of the epiphytic species from the Posidonia prairies to deeper areas and viceversa, supporting the tsunami origin interpretation (see Martini et al., 2010 and Smedile et al., 2011 for discussion).

The hypothesis that these signatures likely represent tsunamis of the past becomes stronger, because, when comparing the ages of the well-known historical tsunamis with the geologic age ranges defined for the high-energy layers, we found a good overlap. A summary of this comparison is presented in Table 1. Although with a first analysis there is a good correlation among the events, there are details that pose some questions. The most outstanding is that albeit the Augusta and Priolo inland sites are facing the same bay and are located ca. $10 \mathrm{~km}$ apart, they have not registered the same high-energy events that we interpreted as tsunamis. This apparent discrepancy likely results from one or a combination of the following circumstances: (1) the two sites experienced different paleoenvironmental histories (i.e. in the last millennium the Augusta Hospital site became an alluvial dominated plain where erosional events did not allow the preservation of the stratigraphy) and represent different intervals of time; (2) potential tsunami deposition at the two sites is strongly affected by the different coastal orientations with respect to the potential tsunami striking waves and also by different proximal bathymetry; (3) the tsunami-related sediment distribution may not be homogeneous along the coast also at short distances and even at the same site, both because of actual non-deposition or because of successive reworking/erosion. All these circumstances are particularly relevant especially when we are dealing with tsunami deposits with thickness of a maximum $10 \mathrm{~cm}$, which is the case of the Augusta Bay.

Moreover, the comparison between the inland and offshore events shows a non-perfect chronological correlation between some events (PR-02 with E5 and Ex and AU-01 with E7 and E8). This can be explained with the fact that the radiocarbon-dated marine samples and the marine curves used for calibration of the ages produce very wide age ranges (as long as $500 \mathrm{yr}$ ) for the events, sometimes overlapping and preventing the definition of unambiguous age intervals.

From contemporary reports and documents, the historical tsunamis that inundated the city of Augusta and surrounding areas occurred in 1908,1693,1542, 1169 and possibly in $365 \mathrm{AD}$ (Tinti et al., 2007). The first four events have a local origin and were triggered by earthquakes; the fifth was due to a far-field event: the huge Crete earthquake. With
Table 1. Historical tsunami occurrences compared to age ranges of the geological tsunami evidence from the Augusta inland (De Martini et al., 2010) and offshore (Smedile et al., 2011). Historical tsunamis are retrieved from Tinti et al. (2007) except for the age of the Santorini event (Friedrich et al., 2006).

\begin{tabular}{|c|c|c|}
\hline Historical tsunami & Inland & Offshore \\
\hline 1908 (Messina) & \multirow{3}{*}{ PR-01 (1420-1690 AD) } & E1 (1820-1920 AD) \\
\hline 1693 & & E2 (1430-1810 AD) \\
\hline 1169 & & E3 (930-1170 AD) \\
\hline & AU-00 (650-770 AD) & $\begin{array}{l}\text { E4 (590-800 AD) } \\
\text { E5 (430-660 AD) }\end{array}$ \\
\hline \multirow[t]{4}{*}{$365 \mathrm{AD}$ (Crete) } & PR-02 (160-320 AD) & $\begin{array}{l}\text { Ex }(90-370 \mathrm{AD}) \\
\text { E6 (350-130 BC) }\end{array}$ \\
\hline & AU-01 (600-400 BC) & $\begin{array}{l}\text { E7 }(580-320 \mathrm{BC}) \\
\text { E8 }(660-400 \mathrm{BC})\end{array}$ \\
\hline & PR-03 (800-600 BC) & E9 $(800-560 \mathrm{BC})$ \\
\hline & AU-02 (975-800 BC) & E10 (1130-810 BC) \\
\hline 3600 BC (Santorini) & PR-04 (2100-1635 BC) & E11 (1720-1200 BC) \\
\hline
\end{tabular}

the exception of the 1542 tsunami, which was probably too small, geological evidence of these events was found in the inland record and/or in the offshore one. Only evidence for the 1693 (PR-01) local tsunami and for the 365 AD Crete event (PR-02) was found also inland. Conversely, all the historical events were pinpointed in the offshore record: 1908 (E1), 1693 (E2), 1169 (E3), 365 AD (Ex). Interestingly, evidence for another geologically well-known tsunami event was found in both records, which is that associated with the gigantic collapse of the Santorini volcano in ca. $3600 \mathrm{BP}$ (Friedrich et al., 2006), found in PR-04 and E11.

We should also underline that consistent ages are found also among the remaining four events from the inland record and those from the offshore one. These are AU-00 and E4, AU-01 and E7 or E8, PR-03 and E9 and AU-02 and E10. Only three of the events from the offshore record remain unmatched.

Taking the three tsunami records individually (Table 1), we can calculate the average tsunami recurrence interval (ATRI) in the Augusta Bay. From the historical record and considering the information about the past millennium as complete, we may derive a $250 \mathrm{yr}$ ATRI (four events between 1908 and 1169). From the inland geological record, seven tsunami inundations between $1693 \mathrm{AD}$ and $1600 \mathrm{BC}$ yield a 550-yr long ATRI (De Martini et al., 2010), whereas, from the offshore record, 12 tsunami signatures between $1908 \mathrm{AD}$ and $1600 \mathrm{BC}$ yield a 320-yr long ATRI (Smedile et al., 2011).

Historic and offshore geological ATRI show a good agreement. Considering that the historical record is clearly the most reliable because it is based on direct observations of the tsunamis, the fact that the offshore data match it well indicates that the proxies used to recognize the offshore tsunami signatures are to be considered reliable. Conversely, the inland data appear to miss some of the events (likely those of small-medium size not able to 
penetrate enough inland) and as a consequence provide a longer ATRI than the historical and offshore ones. This was somehow expected also because coastal areas are affected by important, intermittent erosional and depositional events and are strongly modified by human activities. Thus, some parts of the stratigraphic record may be missing, and thus the record of events can be partial. This is particularly true for the small events that would produce limited sedimentation and in restricted areas near the coastline. The marine environment, instead, is more conservative, and sedimentation is generally continuous, providing a stratigraphic record that is relatively complete.

\section{Implications for tsunami hazard}

The integration of geological and historical data on the tsunamis of the past in the Augusta Bay provides the basis to define some characteristics of tsunamis hitting this area, which is relevant for tsunami hazard assessment. The frequency of important paleotsunami inundations is derived over the past $4 \mathrm{ka}$ from offshore signatures and is of $320 \mathrm{yr}$; this is preferred to the historical ATRI, because it averages recurrence over a longer period of time. Although very powerful for the recognition of paleotsunamis, the offshore approach cannot provide information on the size and extent of the tsunamis. Conversely, the inland approach provides a direct observation of the minimum (see introduction) potential inundation distance for future tsunamis in the area. This is equivalent to the maximum distance from the present coastline, at which paleotsunami sediments were sampled ( $530 \mathrm{~m}$ at the Priolo site). It is interesting to underline that this distance is three times larger than the historical one, which is $165 \mathrm{~m}$ for the 1693 event. Max run-up of $5 \mathrm{~m}$ a.s.l. can be estimated from the Augusta site, in agreement with the 2.4 to $8.0 \mathrm{~m}$ derived from 1963 historical data (Gerardi et al., 2008). Combining the maximum geologically observed inland inundation distance and run-up, a figure of the coastal area prone to future large tsunami inundations is obtained (Fig. 5). This figure, being based on geological data only, does not take into account all the inland and offshore parameters that may impact an actual inundation scenario, so it should be considered as a rough representation.

This work has highlighted the potential and the new perspectives opened by the integration of traditional historical tsunami research and the new geological approaches both inland and offshore and the consequent impact on the assessment of tsunami hazard. The case of the Augusta Bay was certainly unique to perform this integration, and tsunami hazard represents a serious threat for the city of Augusta and for the numerous critical industrial and military facilities facing the bay.

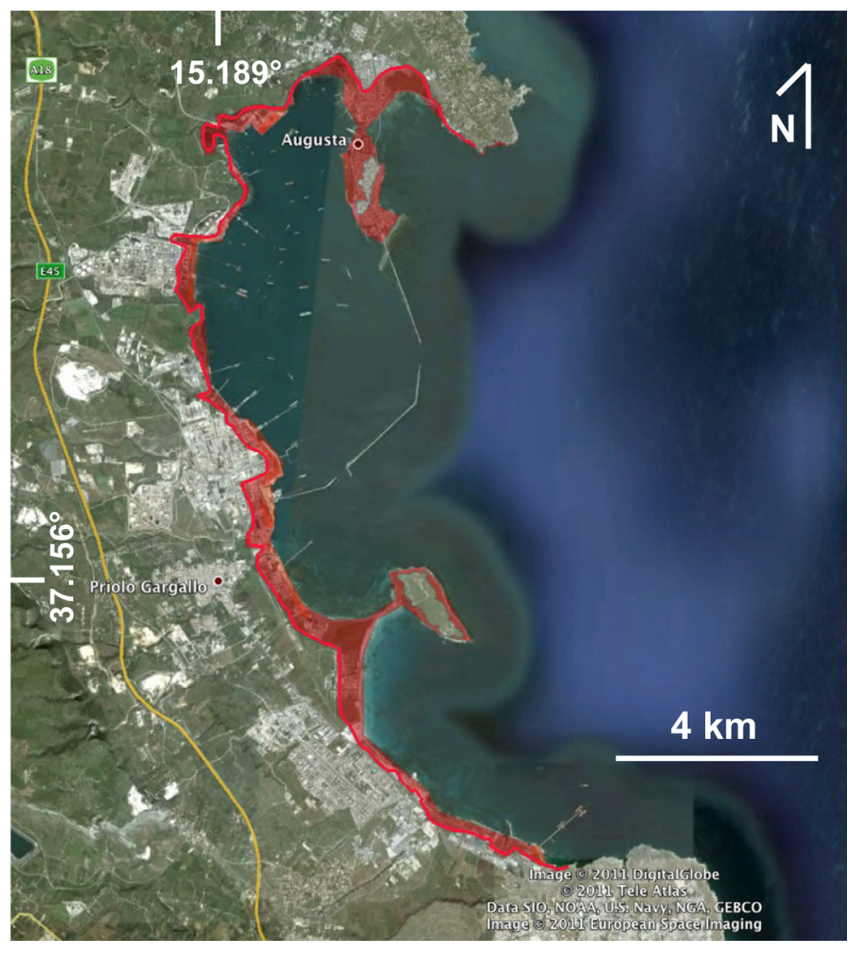

Fig. 5. Map of the coastal area potentially inundated by future large tsunamis (in red) in the Augusta Bay (background from Google Earth). This figure was obtained assuming that the geological observations from paleotsunamis are representative of the worst effects of tsunamis in this area, and thus their inundations may extend up to $500 \mathrm{~m}$ inland and $5 \mathrm{~m}$ a.s.1.

\section{Conclusions}

By integrating the historical record with the geological evidence for high-energy events interpreted as tsunami signatures (Table 1), we reconstructed the tsunami history of the Augusta Bay in eastern Sicily.

The historical record contains evidence for four tsunami events that hit the city of Augusta within the past millennium (1908, 1693, 1542, 1169; Tinti et al., 2007). The geological record was reconstructed both inland and offshore through a detailed multidisciplinary study: seven tsunami deposits were found at the two coastal sites of Priolo and Augusta, whereas 12 tsunami signatures were defined in the stratigraphy of MS-06 core, sampled at about $2 \mathrm{~km}$ distance from the coast at $72 \mathrm{~m}$ b.s.l. Dating of the geological tsunamis evidence was based on ${ }^{14} \mathrm{C}$, tephrochronology, and radioactive tracers $\left({ }^{210} \mathrm{~Pb}\right.$ and $\left.{ }^{137} \mathrm{Cs}\right)$; both records comprise about 4 millennia.

Table 1 shows a chronological comparison of the historical and geological records that highlights the following:

1. evidence for the main historical tsunamis $(1908,1693$, 1169), all of local origin, was found in the inland and/or offshore record with the exception of the 1542 event, 
likely because it was too small to extensively penetrate and deposit in the coastal areas and to perturb the offshore deposition;

2. evidence for two far-generated tsunamis already known in the literature, the $365 \mathrm{AD}$ Crete and $1600 \mathrm{BC}$ Santorini events, was found too;

3. both geological approaches have the potential of extending back in time the record of tsunami inundations of the past, which is generally based only on historical data that rarely exceed the past millennium;

4. the coastal environment is more unstable, and geological signatures of past events may be missing;

5. the marine environment preserves better than the coastal one and provides a record of paleotsunamis that appears to be as complete as the historical one (cf. historical and offshore ATRI);

6. the combining of geological and historical data provides new elements for tsunami hazard assessment (Fig. 5).

Acknowledgements. This work was funded by the Italian Dipartimento della Protezione Civile in the frame of the 2004-2006 and 2007-2009 agreements with Istituto Nazionale di Geofisica e Geofisica e Vulcanologia - INGV with contribution of the EU Transfer project. We have to warmly thank M. S. Barbano, F. Gerardi, C. Pirrotta from Catania University, L. Gasperini, L. Bellucci, A. Polonia from ISMAR-CNR Bologna, P. Del Carlo and E. Boschi from INGV, and P. Guarnieri for their enthusiastic and productive collaboration. A. Cavallo is kindly acknowledged for the assistance of FESEM pictures performed at INGV-Roma. Thanks also to K. Reicherter and an anonymous reviewer for their suggestions that contributed to improve the original manuscript.

Edited by: H. Nelson

Reviewed by: K. Reicherter and another anonymous referee

\section{References}

Abrantes, F., Alt-Epping, U., Lebreiro, S., Voelker, A., and Schneider, R.: Sedimentological record of tsunamis on shallow-shelf areas: The case of the 1969 AD and 1755 AD tsunamis on the Portuguese Shelf off Lisbon, Mar. Geol., 249, 283-293, 2008.

Antonioli, F., Ferranti, L., Fontana, A., Amorosi, A., Bondesan, A., Braitenberg, C., Dutton, A., Fontolan, G., Furlani, S., Lambeck, K., Mastronuzzi, G., Monaco, C., Spada, G., and Stocchi, P.: Holocene relative sea-level changes and vertical movements along the Italian and Istrian coastlines, Quatern. Int., 206, 102-133, 2009.

Atwater, B. F. and Moore, A. L.: A Tsunami About 1000 Years Ago in Puget Sound, Washington, Science, 258, 1614-1617, 1992.

Barbano, M. S., Pirrotta, C., and Gerardi, F.: Large boulders along the south-eastern Ionian coast of Sicily: storm or tsunami deposits?, Mar. Geol., 275, 140-154, 2010.
Bondevik, S., Svendsen, J. I., and Mangerud, J.: Tsunami sedimentary facies deposited by the Storegga tsunami in shallow marine basins and coastal lakes, western Norway, Sedimentology, 44, 1115-1131, 1997.

Bronk Ramsey, C.: Deposition models for chronological records, Quatern. Science Rev., 27, 42-60, 2008.

Bronk Ramsey, C.: Bayesian analysis of radiocarbon dates, Radiocarbon, 51, 337-360, 2009.

Carbone, S.: I depositi pleistocenici del settore nord-orientale ibleo tra Agnone e Melilli (Sicilia SE): relazione tra facies e lineamenti strutturali, Boll. Soc. Geol. It., 104, 171-191, 1984.

Cita, M. B. and Aloisi, G.: Deep-sea tsunami deposits triggered by the explosion of Santorini (3500 yr BP), eastern Mediterranean, Sediment. Geol., 135, 181-302, 2000.

Cochran, U. A., Berryman, K. R., Zachariasen, J., Mildenhall, D. C., Hayward, B. W., Southall, K., Hollis, C. J., Barker, P., Wallace, L., Alloway, B., and Wilson, K.: Paleoecological insights into subduction zone earthquake occurrence, eastern North Island, New Zealand, GSA Bulletin, 118, 1051-1074, 2006

CPTI Working group: Catalogo Parametrico dei Terremoti Italiani, version 2004 (CPTI04), INGV, Bologna, available at: http:// emidius.mi.ingv.it/CPTI/ last access: September 2011.

Dawson, A. G. and Stewart, I.: Tsunami deposits in the geological record, Sediment. Geol., 200, 166-183, 2007.

Dawson, A. G., Hindson, R., Andrade, C., Freitas, C., Parish, R., and Bateman, M.: Tsunami sedimentation associated with the Lisbon earthquake of 1 November AD 1755: Boca do Rio, Algarve, Portugal, Holocene, 5, 209-215, 1995.

De Martini, P. M., Burrato, P., Pantosti, D., Maramai, A., Graziani, L., and Abramson, H.: Identification of liquefaction features and tsunami deposits in the Gargano area (Italy): a geologic contribution to the hazard assessment, Ann. Geophys., 46, 883-902, 2003,

http://www.ann-geophys.net/46/883/2003/.

De Martini, P. M., Barbano, M. S., Smedile, A., Gerardi, F., Pantosti, D., Del Carlo, P., and Pirrotta, C.: A 4000 yr long record of tsunami deposits along the coast of the Augusta Bay (eastern Sicily, Italy): paleoseismological implications, Mar. Geol., 276, 42-57, doi:10.1016/j.margeo.2010.07.005, 2010.

Dominey-Howes, D. T. M., Cundy, A. B., and Croudace, I.: High energy marine flood deposits on Astypalaea Island, Greece: possible evidence for the AD 1956 southern Aegean tsunami, Mar. Geol., 163, 352-361, 2000.

Friedrich, W. L., Kromer, B., Friedrich, M., Heinemeier, J., Pfeiffer, T., and Talamo, S.: Santorini eruption radiocarbon dated to 1627 e 1600 B.C, Science, 312, 5773, doi:0.1126/science.1125087, 2006.

Gelfenbaum, G. and Jaffe, B.: Erosion and sedimentation from the 17 July 1998 Papua New Guinea tsunami, Pure Appl. Geophys., 160, 1969-1999, 2003.

Gerardi, F., Barbano, M. S., De Martini, P. M., and Pantosti, D.: Discrimination of tsunami sources (earthquake vs. landslide) on the basis of historical data in eastern Sicily and southern Calabria, Bull. Seismol. Soc. Am., 98, 2795-2805, 2008.

Gianfreda, F., Mastronuzzi, G., and Sansò, P.: Impact of historical tsunamis on a sandy coastal barrier: an example from the northern Gargano coast, southern Italy, Nat. Hazards Earth Syst. Sci., 1, 213-219, doi:10.5194/nhess-1-213-2001, 2001. 
Goodman-Tchernov, B. N., Dey, H. W., Reinhardt, E. G., McCoy, F., and Mart, Y.: Tsunami waves generated by the Santorini eruption reached Eastern Mediterranean shores, Geology, 37, 943-946, 2009.

Goto, K., Chagué-Goff, C., Fujino, S., Goff, J., Jaffe, B., Nishimura, Y., Richmond, B., Sugawara, D., Szczuciński, W., Tappin, D. R., Witter, R. C., and Yulianto, E.: New insights of tsunami hazard from the 2011 Tohoku-oki event, Mar. Geol., 290, 46-50, 2011.

Grasso, M., Lentini, F., and Pedley, H. M.: Late Tortonian-Lower Messinian (Miocene) palaeogeography of SE Sicily: information from two new formations of the Sortino Group, Sediment. Geol., 32, 279-300, 1982.

Hindson, R., Andrade, C., and Parish, R.: A microfaunal and sedimentary record of environmental change within the late Holocene sediments of Boca do Rio (Algarve, Portugal), Geologie en Mijnbouw, 77, 311-321, 1999.

Jerome: Chonicon Eusebii, Eusebius Chonicon, edited by: Helm, R., GSC 47, Berlin, 380.

Jorissen, F. J.: The distribution of benthic Foraminifera in the Adriatic Sea, Mar. Micropal., 12, 21-48, 1987.

Mastronuzzi, G., Pignatelli, C., Sansò, P., and Selleri, G.: Boulder accumulations produced by the 20th of February, 1743 tsunami along the coast of southeastern Salento (Apulia region, Italy), Mar. Geol., 242, 191-205, 2007.

Minoura, K., Imamura, F., Kuran, U., Nakamura, T., Papadopoulos, G. A., Takahashi, T., and Yalciner, A. C.: Discovery of Minoan tsunami deposits, Geology, 28, 59-62, 2000.

Morton, R. A., Gelfenbaum, G., and Jaffe, B. E.: Physical criteria for distinguishing sandy tsunami and storm deposits using modern examples, Sediment. Geol., 200, 184-207, 2007.

Reimer, P. J. and Reimer, R. W.: A marine reservoir correction database and on-line interface, Radiocarbon 43, 461-463, (Supplement http://www.calib.org), 2001.

Reinhardt, E. G., Goodman, B. N., Boyce, J. I., Lopez, G., van Hengstum, P., Rink, W. J., Mart, Y., and Raban, A.: The tsunami of 13 December A.D. 115 and the destruction of Herod the Great's harbor at Caesarea Maritima, Israel, Geology, 34, 1061-1064, 2006.
Scicchitano, G., Monaco, C., and Tortorici, L.: Large boulder deposits by tsunami waves along the Ionian coast of south-eastern Sicily (Italy), Mar. Geol., 238, 75-91, 2007.

Shiki, T., Tachibana, T., Fujiwara, O., Goto, K., Nanayama, F., and Yamazaki, T.: Characteristic features of tsunamiites, in: Tsunamiites - Features and Implications, edited by: Shiki, T., Tsuji, Y., Yamazaki, T., and Minoura, K., Elsevier, Amsterdam, 319-340, 2008.

Smedile, A., De Martini, P. M., Pantosti, D., Bellucci, L., Del Carlo, P., Gasperini, L., Pirrotta, C., Polonia, A., and Boschi, E.: Possible tsunamis signatures from an integrated study in the Augusta Bay offshore (Eastern Sicily-Italy), Mar. Geol., 281, $1-13,2011$.

Stuiver, M. and Reimer, P. J.: Radiocarbon calibration program CALIB REV5.0.2, copyright, available at: http://calib.cub.ac.uk/ calib/ (last access: 2009), 2005.

Sugawara, D., Minoura, K., and Imamura, F.: Tsunamis and tsunami sedimentology, in: Tsunamiites - Features and Implications, edited by: Shiki, T., Tsuji, Y., Yamazaki, T., Minoura, K., Elsevier, Amsterdam, 9-49, 2008.

Tinti, S., Maramai, A., and Graziani, L.: The Italian Tsunami Catalogue (ITC), Version 2, available at: http://www.ingv.it/servizi-e-risorse/BD/catalogo-tsunami/ catalogo-degli-tsunami-italiani (last access: September 2011), 2007.

van den Bergh, G. D., Boer, W., Haas, H., van Weering, T., and van Wijhe, R.: Shallow marine tsunami deposits in Teluk Banten (NW Java, Indonesia), generated by the 1883 Krakatau eruption, Mar. Geol., 197, 13-34, 2003.

Weiss, R. and Bahlburg, H.: A note on the preservation of offshore tsunami deposits, J. Sediment. Res., 76, 1267-1273, 2006. 